\title{
Recenzja: Scott Barry Kaufman, Carolyn Gregoire Kreatywni. I masz pomysł na wszystko, tłum. K. Mojkowska, Wyd. Muza, Warszawa 2018
}

\begin{abstract}
Abstrakt
Omawiana książka jako pozycja przybliżająca zagadnienie kreatywności spełni swoją rolę przede wszystkim wobec osób dopiero wkraczających $w$ tę dziedzinę wiedzy albo nastawionych na poszukiwanie ciekawostek. Nie należy jednak podchodzić do jej treści bezkrytycznie, lecz traktować ją jako punkt wyjścia do dalszych poszukiwań.
\end{abstract}

\section{Review: Scott Barry Kaufman, Carolyn Gregoire, Wired to Create. Unraveling the Mysteries of the Creative Mind, [Muza Publishing House], Warsaw 2018 (in Polish translation)}

\begin{abstract}
The book reviewed as an item presenting the issue of creativity can play its role in case of persons who just enter this field of knowledge or persons who are seeking curiosities. It should not be approached uncritically, but treated as a starting point for further explorations.
\end{abstract}

Kreatywność jest uznawana obecnie za jeden z ważniejszych wyznaczników wszechstronnie rozwiniętej osobowości, wspieranie jej rozwoju uznaje się zaś za istotny element edukacji i wychowania. Stąd nie brak publikacji pedagogicznych i psychologicznych poświęconych temu zagadnieniu. Wśród nich można wyróżnić trzy główne typy: publikacje naukowe, publikacje metodyczne, zajmujące się dydaktyką twórczości, oraz publikacje popularnonaukowe przybliżające to zagadnienie szerokiemu gronu odbiorców. Najnowsza książka wydana przez wydawnictwo Muza sytuuje się w trzeciej z wymienionych grup. Ta pozycja posiada wszystkie zalety i wszystkie wady książek popularnonaukowych.

* Uniwersytet Łódzki, Wydział Nauk o Wychowaniu, Katedra Edukacji Artystycznej i Pedagogiki Twórczości. 
Książkę stworzyli wspólnie doktor Scott Barry Kaufman, dyrektor do spraw naukowych Instytutu Wyobraźni w Centrum Psychologii Pozytywnej Uniwersytetu w Pensylwanii, współzałożyciel portalu „The Creativity Post”, oraz Carolyn Greogire, dziennikarka publikująca teksty z dziedziny psychologii, zdrowia psychicznego i neurobiologii. Taki dobór autorów zwiększa prawdopodobieństwo, że publikacja będzie łączyć rzetelność naukową oraz przystępność dla szerokiego odbiorcy.

Autorzy omawiają dyskutowane od dawna na różne sposoby i z wielu punktów widzenia zjawisko kreatywności. Dowodzą, że jest ona połączeniem wrodzonych predyspozycji oraz wpływów wychowania i środowiska, a także aktywności własnej. Prawidłowości funkcjonowania, myślenia i zachowania ludzi uważanych za kreatywnych zostały przedstawione $\mathrm{w}$ formie dziesięciu najważniejszych cech, określonych przez autorów jako „nawyki umysłu”. Są to: umiejętność kreatywnej zabawy, oddawanie się pasji, śnienie na jawie, potrzeba samotności i umiejętność do czerpania natchnienia z sytuacji bycia samemu, intuicja, otwartość na doświadczenia, uważność, wrażliwość, przekuwanie przeszkód w swoją korzyść oraz odwaga nieszablonowego myślenia. Każda z tych cech została przedstawiona przez pryzmat psychologicznych eksperymentów oraz poparta przykładami z życia ludzi kreatywnych. Autorzy przywołują między innymi postacie Fridy Kahlo, Thomasa Edisona, Johna Lennona, Michaela Jacksona, Shigeru Miyamoto (twórcy popularnej gry Mario Bros i konsoli Wii), Audrey Hepburn i wielu innych. Dobór przykładów zasługuje na uznanie, gdyż $\mathrm{w}$ wielu pozycjach o kreatywności można przeczytać tylko o artystach, podczas gdy wynalazcy, uczeni, odkrywcy, podróżnicy także odznaczają się wysokim poziomem kreatywności, bez czego nie zdołaliby osiągnąć swoich celów. Przykładów w omawianej książce jest bardzo wiele, jednak wszystkie zostały omówione bardzo skrótowo, niemal w postaci wzmianek, co budzi niedosyt czytelnika. Przykłady lepiej spełniłyby swoją rolę, gdyby choć jeden przypadek w odniesieniu do każdej z dziesięciu cech autorzy przedstawili bardziej wyczerpująco.

Przedstawiane informacje zostały skrupulatnie udokumentowane, poparte przypisami i odniesieniami do literatury. Przypisy i bibliografia zajmują aż 70 stron, wszystkie pozycje pochodzą z ostatnich kilku lat. Znajdują się wśród nich prace naukowców polskich, między innymi Romana Ossowskiego, Stanisława Betlejewskiego i Kazimierza Dąbrowskiego.

Sukces rynkowy książki popularnonaukowej w znacznym stopniu zależy od przekładu. Nie jest to łatwe, gdyż tłumacz musi zachować precyzję terminologiczną, a jednocześnie zadbać o komunikatywność i typowy dla współczesnych książek popularnonaukowych „gawędziarski” styl pisania. Katarzyna Mojkowska wywiązała się z tych zadań w różnym stopniu. Udało jej się zachować swobodę i komunikatywność wypowiedzi. Książkę czyta się łatwo i lekko, wciąga czytelnika i przykuwa uwagę. Jednocześnie jednak tłumaczka nie ustrzegła się błędów językowych (choćby nieszczęsnego „najbardziej optymalnie”) oraz niezręczności składniowych i językowych (na przykład „poddawali się ewaluacjom życia osobistego” lub „wyso- 
ko kreatywna twórczość”, co błędnie sugeruje istnienie twórczości niekreatywnej). Największy zarzut stanowią jednak pomyłki merytoryczne, które także się tutaj pojawiają. Z kontekstu można wywnioskować, że wynikają one z nieznajomości terminologii psychologicznej i pedagogicznej. I tak, angielskie słowo „creative” tłumaczka przekłada zawsze na „kreatywny”, choć niekiedy powinno ono brzmieć: „twórczy”. Nie używa się bowiem w języku polskim określenia „pedagogika kreatywności”, lecz „pedagogika twórczości”. Należałoby się także zastanowić, czy na pewno polska wersja tytułu trafnie oddaje intencje autorów. Tytuł Wired to Create. Unraveling the Mysteries of the Creative Minds, co oznacza dosłownie: Podekscytowany, aby tworzyć. Odkrywanie tajemnic twórczego umysłu przetłumaczono na: Kreatywni. I masz pomysł na wszystko. Tytuł książki, podobnie jak tytuł filmu czy piosenki, nie musi być oczywiście dosłowny, powinien jednak trafnie oddawać intencje autorów. Wydaje się, że Scott Barry Kaufman i Carolyn Greogire położyli nacisk na wtajemniczanie czytelników w sposób pracy umysłów ludzi twórczych, podczas gdy polska wersja zapowiada zbiór łatwych przepisów, prowadzących prostą drogą do kreatywności.

Wartościowe i cenne poznawczo są fragmenty książki, traktujące o zależnościach między różnymi przejawami kreatywności a sposobem pracy ludzkiego mózgu. Znaczące odkrycia na tym polu zostały dokonane dopiero w ostatnich latach i można sądzić, że zarówno ten kierunek badań, jak i refleksja nad ich wynikami będą się dynamicznie rozwijać, a refleksje stymulowane tymi informacjami staną się ważną dziedziną pedagogiki i psychologii twórczości.

Nie wszystkie zawarte w książce informacje są równie ciekawe, w każdym razie z punktu widzenia osoby, której pewna część literatury na temat kreatywności nie jest obca. Niekiedy można odnieść wrażenie, że przytaczane wyniki badań mają na celu potwierdzić jedynie dobrze znane prawidłowości codziennego życia. Nie wzbudza podziwu dla pracy naukowców takie na przykład stwierdzenie: „Psychologowie poznawczy odkryli niedawno, że dźwięk wibracji twojego telefonu może znacznie zakłócić koncentrację". W innym miejscu autorzy piszą z zachwytem: „Simonton odkrył, że najsłynniejsi kompozytorzy operowi mieszają w swoich kompozycjach operowych różne gatunki muzyczne, a po godzinach tworzą również nieoperowe utwory" - Simonton nie mógł tego odkryć w 2014 r. (data publikacji artykułu), gdyż jest to prawidłowość dobrze znana muzykom i muzykologom od kilkuset lat. Wielość odniesień do literatury psychologicznej, choć jest wartością książki, budzi zaniepokojenie czytelnika zauważającego powyższe uproszczenia wszystkich podanych odniesień nie da się wszak samodzielnie sprawdzić i zanalizować, można więc żywić obawy, że tekst zawiera więcej podobnych nieścisłości. Nie ma wątpliwości, że od książki popularnonaukowej, zwłaszcza pisanej przez aktywnego naukowca-badacza, można oczekiwać rzetelności nie mniejszej niż ta, której wymaga się od recenzowanych i indeksowanych prac naukowych; różnica powinna tkwić nie w warsztacie, lecz w wyborze informacji i sposobie ich przekazania odbiorcy. 
Wątpliwości budzi rozdział wprowadzający w prawidłowości funkcjonowania ludzi kreatywnych, czyli wspomniane już „nawyki umysłu”; otóż, za wyróżniającą twórców cechę, stanowiącą punkt wyjścia do dalszych rozważań, uznano... chaos. Wydaje się to co najmniej dyskusyjne - wszak chaos to nie to samo co niejednorodność, złożoność, umiejętność łączenia sprzeczności. Określenia „chaos” czy nawet, jak napisano w pewnym momencie, „bajzel” sugerują bałagan i brak jakichkolwiek prawidłowości, a przecież prawidłowości te w dalszej części książki są właśnie omawiane.

Kreatywność należy do zagadnień naukowych, którymi nie sposób interesować się czysto teoretycznie - podczas czytania, prędzej czy później, pojawiają się skojarzenia z własnym życiem i doświadczeniami oraz wnioski dotyczące siebie samego lub osób najbliższych. Książka popularnonaukowa powinna w takiej sytuacji rozbudzić u czytelnika chęć sprawdzenia nowo zdobytej wiedzy w praktyce i motywować do wprowadzenia zmiany. Omawiana pozycja jest pod tym względem nierówna: za bardzo motywujący można uznać rozdział Przekuwanie przeszkód $w$ swojq korzyść, który wskazuje na potencjalne pozytywne strony traumatycznych życiowych wydarzeń, a jednocześnie wyraźnie zaznacza, że trauma nie jest warunkiem niezbędnym do tworzenia; rozdział Wrażliwość wprowadza z kolei wiele uproszczeń i niedopowiedzeń, które działają demotywująco. Zawarty w tym rozdziale test wrażliwości wewnętrznej i bogatego życia wewnętrznego nie posiada żadnego omówienia, jedynie lakoniczną zapowiedź: „Jeśli jesteś zainteresowany, jak wypadasz w kwestii tych dwóch głównych czynników, rozwiąż test”. Nie wiadomo, jak zinterpretować wyniki i jak zareagować na ewentualną wiadomość o niskim poziomie wrażliwości, która w świetle kreatywności jest niekorzystna: czy da się ją rozwijać, stymulować? A jeśli nie, czy mimo to można być kreatywnym? Autorzy pozostawiają czytelnika z tymi pytaniami bez pomocy.

Grono potencjalnych odbiorców książki Kreatywni. I masz pomysł na wszystko jest liczne i zróżnicowane. Należą tu osoby wprowadzające do swojej pracy elementy pedagogiki twórczości, np. nauczyciele, wychowawcy, trenerzy personalni; rodzice, którzy chcą świadomie wychowywać swoje dzieci; naukowcy i studenci pokrewnych dziedzin nauki; wreszcie - wszyscy zainteresowani samorozwojem, funkcjonowaniem ludzkiego mózgu i psychiki w zróżnicowanym i bogatym w bodźce świecie. Wykładowcom i trenerom pozycja ta może dostarczyć ciekawych przykładów do egzemplifikacji przedstawianych tez. Jeśli jednak ktoś liczy na relację z nowych, przełomowych badań lub całkowicie nowe spojrzenie na szeroko dyskutowaną problematykę twórczości - książka nie spełni jego oczekiwań. Oferuje bowiem przede wszystkim ustrukturyzowanie pewnych informacji i inne ujęcie prawidłowości już znanych.

Reasumując, omawiana książka jako pozycja przybliżająca zagadnienie kreatywności spełni swoją rolę przede wszystkim wobec osób dopiero wkraczających w tę dziedzinę wiedzy albo nastawionych na poszukiwanie ciekawostek. Nie należy jednak podchodzić do jej treści bezkrytycznie, lecz traktować ją jako punkt wyjścia do dalszych poszukiwań. 